\title{
Truancy and Academic Performance of Secondary School Students in Southwestern Nigeria: Implications for Counselling
}

\author{
Fareo Dorcas Oluremi \\ Faculty of Education, Obafemi Awolowo University, Nigeria
}

\begin{abstract}
This study identified the relationship between truancy and academic performance of secondary school students in Southwestern Nigeria. It also examined the relationship between school physical environment and truancy behavior among students. It also investigated the deference between male and female manifestation of truancy behavior. Stratified sampling technique was used to select 360 sample size from four secondary schools in four out of six states in Southwestern Nigeria. Three research instruments were used for this study namely, Academic Records of Students, Attendance Registers and "School Environment Questionnaire" (SEQ), Four hypotheses were raised and tested using chisquare and t-test analysis. The study revealed that there was a significant relationship between truancy and academic performances of students; there was not a significant relationship between the school physical environment and truancy behavior among students; there was not a significant difference between the academic performance of male and female truants. However, there was a significant difference between male and female manifestation of truancy behavior. The study concluded that truancy hindered effective learning and could lead to poor academic performance.
\end{abstract}

\section{Introduction}

Truancy is one of the major antisocial discipline problems among secondary school students in Nigeria. The concept and acts of indiscipline have received a lot of attention by researchers. Peck opined that the various behavioural disorders like stealing, violence, drug abuse, examination malpractice, sexual abuse and truancy have so undermined effective teaching-learning processes that some teachers have become helpless and disorganized in their task of impacting knowledge to the learners [35].

Ma'aruf identified four major home factors as being responsible for truancy namely [25]:

(a) Poor relationship between children and parents;

(b) Poor physical conditions at home;

(c) Use of corporal punishment in the house;

(d) Lack of parental interest in the child's welfare.
The school has also been identified as a strong factor responsible for truancy. Adewole reported that breakdown of communication, student over population, shortage of teachers, incessant strike and work-to-rule, undue application of corporal punishment as well as peer influence at school are strongly associated with truancy [4]. Kirk, Malcilm, Wilson and Davidson identified causes of truancy as bullied by school staff, boredom, dislike of teachers and avoidance of tests [24].

Ubogu identified causes of truancy as illness, financial hardship, age, social class, geographical area, and institutional influence schools related factors such as teachers attitude, poor administration, high cost of education [43]. Distance to school, school discipline, family background and school location are among causes of truancy among school students 2005 [16]. Siziya, Muula and Rudatsikira in their study found that truancy adolescents had been reported to engage in risky sexual practice, illicit drug use, alcohol drinking and cigarette smoking [41].

Carrol found that truancy and poor attendance to school are most likely to be found among large families where the father is a manual worker [14]. Similarly, Brillingston [9] and Ma'aruf [25] in their studies, discovered a high correlation between home circumstances and persistent truancy without the knowledge of the parents. Truancy could result into poor academic achievement, losing friends and partners, and disruption in class. Absentees return affect the behavior of other students, difficulty in keeping accurate records, reduced ability to meet instructional targets and damaged school reputation [31].

Studies have shown that attendance of students have positive relationship with their academic performance [27, 31] According to Emore, lateness was common among female students than male students [16]. This was as a result of their involvement in domestic activities by their parents.

Obemeata, Adeboyeje and Obayan studies revealed that school physical environment exert some dominant influence on learners' academic performance [2, 28, 29]. However, Akinwumi and Ayeni, Fareo and Okotoni gave contrary views that there was no significant relationship between physical environment and academic performance of students [17]. This unending problems of truancy 
and poor academic performance of secondary school students call for a study like this.

\section{Hypotheses}

The following hypotheses were formulated

$\mathrm{HO}_{1}$ : There is no significant relationship between truancy and academic performance of students.

$\mathrm{HO}_{2}$ : There is no significant relationship between school physical environment and truancy of students.

$\mathrm{HO}_{3}$ : There is no significant difference between the academic performance of male and female truants.

$\mathrm{HO}_{4}$ : There is no significant difference between male and female manifestation of truancy behavior.

\section{Methodology}

The study was a descriptive survey design. The population for this study consists of all junior secondary school students in Southwestern Nigeria. However, the sample of 360 was drawn from four out of the six states in Southwestern Nigeria (Lagos, Osun, Ogun and Ekiti States), one secondary school was selected from each state by simple random sampling technique. Stratified sampling technique was used to select 80 students from each of the states.

The three instruments used to collect data for this study were academic records of students' performance, attendance registers for 2010//2011 session and School Environment Questionnaire (SWQ).

The cumulative academic performance for 2010/2011 session was 100, cumulative attendance was 100, while School Environment Questionnaire was a twenty five items questionnaire patterned after five Likert point scale. For the purpose of validation, the face and content validity was carried out by two experts in Test and Measurement, from the Department of Educational Foundations and Counselling, Faculty of Education, Obafemi Awolowo University, Ile-Ife. Appropriate suggestions were made to improve the quality of the questionnaire. The test-retest reliability method of "SEQ" was carried out two weeks after the first test and the test-retest yielded a reliability co-efficient of 0.74 that is significant at 0.05 level $(\mathrm{n}=40 \mathrm{r}=0.74, \mathrm{P}$ $<0.05)$. Data were analyzed using chi-square and ttest analysis.

\section{Results}

Hypothesis 1: There is no significant relationship between truancy and academic performance of students. The hypothesis was tested using chi-square analysis. The results are presented in Table 1.

Table 1. Relationship between Truancy and Academic Performance of Students

\begin{tabular}{|c|c|c|c|c|c|c|c|}
\hline \multirow{2}{*}{$\begin{array}{c}\text { Categories of } \\
\text { Attendance }\end{array}$} & \multicolumn{7}{|c|}{ Academic Performance } \\
\hline & $\begin{array}{l}\text { Poor } \\
0-25\end{array}$ & $\begin{array}{c}\text { Fairly Good } \\
26-50\end{array}$ & $\begin{array}{l}\text { Good } \\
51-75\end{array}$ & Total & $x_{2}$ & df & $\mathbf{P}$ \\
\hline Exhibit truancy $0-38$ & 7 & 3 & 0 & 10 & & & \\
\hline $\begin{array}{l}\text { Fairly exhibit truancy } \\
39-76\end{array}$ & 10 & 25 & 14 & 49 & 24.66 & 4 & $<.05$ \\
\hline $\begin{array}{l}\text { Regular in school 77- } \\
114\end{array}$ & 40 & 164 & 95 & 299 & & & \\
\hline Total & & 57 & 192 & 109 & 358 & & \\
\hline
\end{tabular}

The relationship between truancy and academic performance of students was found to be significant with a chi-square value of 24.66 which was significant at 0.05 . Implying there was a significant relationship between truancy and academic performance of students.

Hypothesis 2: There is no significant relationship between the school physical environment and truancy among students. The hypothesis was tested using chi square analysis.

Table 2. Relationship between School Physical Environment and Truancy among Students

\begin{tabular}{|c|c|c|c|c|c|c|c|}
\hline Categories of Attendance & \multicolumn{7}{|c|}{ Academic Performance } \\
\hline & $\begin{array}{l}\text { Poor } \\
0-25\end{array}$ & $\begin{array}{c}\text { Fairly Good } \\
26-50\end{array}$ & $\begin{array}{l}\text { Good } \\
51-75\end{array}$ & Total & $x_{2}$ & df & $P$ \\
\hline Exhibit truancy 0-38 & 1 & 9 & 0 & 10 & & & \\
\hline Fairly exhibit truancy $39-76$ & 3 & 44 & 2 & 49 & 1.64 & 4 & $>0.05$ \\
\hline Regular in school $77-114$ & 19 & 258 & 22 & 299 & & & \\
\hline Total & 23 & 311 & 24 & 358 & & & \\
\hline
\end{tabular}

Relationship between school physical environment and truancy was found not significant with a chi-square value of 1.64 , which was not significant at 0.05 . Implying there was not a significant relationship between the school physical environment and truancy among students.

Hypothesis 3: There is no significant difference between the academic performance of male and female truants. The hypothesis was tested using t-test analysis.

Table 3: Difference between Academic Performance of Male and Female Truants

\begin{tabular}{|l|l|l|l|l|l|l|}
\hline $\begin{array}{c}\text { Academic } \\
\text { Performance }\end{array}$ & \multicolumn{1}{|c|}{ N } & \multicolumn{1}{|c|}{$\bar{x}$} & \multicolumn{1}{c|}{ SD } & t & df & P \\
\hline Male & 190 & 2.10 & 0.70 & -1.37 & 356 & $>0.05$ \\
\hline Female & 168 & 2.20 & 0.62 & & & \\
\hline
\end{tabular}


The mean of male students' academic performance was 2.10 , while the mean of academic performance of female students was 2.20. The difference between the academic performance of male and female truants was found not to be significant with a t-test value of $-1.371(\mathrm{P}>0.05)$.

Hypothesis 4: There is no significant difference between male and female manifestation of male and female truancy behavior. The hypothesis was tested using t-test analysis.

Table 4: Difference between Male and Female Manifestation of Truancy Behaviour

\begin{tabular}{|l|c|c|c|c|c|c|}
\hline \multicolumn{1}{|c|}{$\begin{array}{c}\text { Truancy } \\
\text { Behaviour }\end{array}$} & \multicolumn{1}{|c|}{ N } & \multicolumn{1}{c|}{$\bar{x}$} & \multicolumn{1}{c|}{ SD } & t & df & P \\
\hline Male & 190 & 2.74 & 0.54 & -2.88 & 356 & P 0.05 \\
\hline Female & 168 & 2.88 & 0.34 & & & \\
\hline
\end{tabular}

The mean of male manifestation of truancy behavior was 2.74, while that of female was 2.88 . The difference between male and female manifestation of truancy behaviour was found to be significant with a t-test value of $-2.88(\mathrm{P}<0.05)$.

\section{Discussion}

The study revealed that there was a significant relationship between truancy and academic performance of students. The finding agrees with Nwadiani [27], Oghuvbu [31] and Ogbuvbu [32]. Truancy could result into poor academic achievement, loosing friends and parties and disruption in class.

The study also found that there was not a significant relationship between the school physical environments and truancy behaviour among students. The study corroborated with Akinwumi and Ayeni [6], but was contrary to Obemeata [29], Adeboyeje [2] and Obayan [28] which revealed that classroom environment exert some dominant influence on learners' academic performance. Poor school physical environment with problems of inadequate chairs and tables, lack of space to move freely in the classrooms due to overcrowding of students in small size classes could constitute barriers and obstacles to learning. The unhealthy physical environment could also lead to absenteeism or truancy of students.

The study found that there was not a significant difference between the academic performance of male and female truants. This implied that the truants boys and girls were of low intellectual capabilities', and the anti-social problems had set a limitation to their academic performance. This observation was similar to Akinpelu's finding [25] that there was no significant difference between the academic achievement of male and female hearing impaired student.
The study also found that there was a significant difference between male and female manifestation of truancy behavour. The results in Table 4 showed that the boys were more involved in truancy than girls. The finding supported earlier findings by Singh [40]; Adamu [1], Adewole [4], Ma'aruf [25], and Adeloye, [3]. The aggressive nature of boys tends to push them to manifest various acts of misbehavior.

\section{Conclusion}

The study concluded that truancy hinders effective learning and could lead to poor academic performance of truants. Constant absence from school has serious negative consequences both for truant youth themselves and for communities, which suffer both short and long-term threats to public safety.

\section{Implications for Counselling}

Parents should put more effort to ensure that their children are adequately provided for and morally groomed. The increasing student enrolment at all levels of education should be matched with corresponding professionally qualified teachers. There should be enlightenment campaigns by government agencies, and non-government organizations for parents and children on the dangers inherent in truancy.

Teachers and counsellors should invite parents of truants for conference with a view to reducing the incidence of truancy in schools. The current practice of appointing career masters to perform the role of professional counsellors should stop, so that functional guidance services could be provided for students. The school authority and teachers should ensure conducive school physical environment for good working relationship between teachers and students. School administrators should supervise adequately the keeping and utilization of attendance registers for effective control of student for higher academic performance. This is possible because, attendance records will help parent, ministry of education officials and researchers identify other factors affecting students' academic performance and discipline in schools.

\section{References}

[1] Adamu, B.S. (1987), A comparison of teachers' and pupils' views in Nigerian secondary schools. Nigerian Journal of Guidance and Counselling, 3, (1), 16-29.

[2] Adeboyeje, R.A. (2000). A practical approach to effective utilization and maintenance of physical facilities in secondary school. In Fadipe, J.O. \& Oluchukwu, E.E. (eds). Educational Planning and Administration in Nigeria. Ondo. NIEPA, 88-103. 
[3] Adeloye, J.A. (2008). Truancy among secondary school students in Kano Metropolis: Incidence and causes. Conference Proceeding. Official Publication of the Counselling Association of Nigeria (CASSON).

[4] Adewole, E.E. (1988). Truancy in secondary schools; causes, remedies and implications for administration. Ife Journal of Theory and Practice in Education, 2, 4-17.

[5] Akinpelu, O.F. (1998). A study of the academic achievement and self-concept of male and female hearing - impaired students in Nigeria. The Nigerian Journal of Guidance and Counselling, 6 (1\&2), 1-10.

[6] Akinwumi, F.S. \& Ayeni, A.O. (2003). Training manpower factors and students' academic performance in economics in Ibadan South West Local Government Area, Oyo State, Nigeria. Journal of Clinical Counselling Psychology, Vol. 9, No. 1, pp 109-121.

[7] Baker, M.L., Sigmon, J.N., \& Nugent, M.E. (2001). Truancy reduction: Keeping students in school. Office of Juvenile Justice and Delinquency Prevention Bulletin. http://www.ncjrs.gov/html/ojjdp/jjbul2001_9_1/contents.ht $\mathrm{ml}$

[8] Berg, B. L. (2002). Qualitative research methods for the social sciences. Allyn and Bacon Boston.

[9] Brillington, B.J. (1998). Patterns of attendance and truancy. Journal of Educational Psychology, 73, 104-116.

[10] Britten, (2002). Using metal ethnography to synthesize qualitative research: a worked example. Journal of Health Services Research \& Policy, 7:209-215

[11] Brown, D.(1983) Truants, families and schools: A critique of the literature on truancy: Educational Review; 35(3):225-235

[12] Broadwin, I. T. (1932). "A contribution to the study of truancy." American Journal of Orthopsychiatry. 2: 253259.

[13]Capps, W. R. (2003). "The New Face of Truancy." School Administrator 60(4): 5-13.

[14] Carrol, H. (1996). Truancy, absenteeism and delinquency, Scottish Educational Studies, 14-28.

[15] Corville-Smith, J. (1995). "Truancy, family processes, and intervention." The family school connection: Theory, research and practice: $270-287$.

[16] Emore, C. (2005). Causes of students lateness to school in Uvwie L.G.A. of Delta State. Unpublished Post Graduate Diploma in Education Project, Delta State, University, Abraka, Nigeria.

[17] Fareo, D.O. \& Okotoni, C.A. (2009). Classroom environment and effective learning among secondary schools in Ife East Local Government Area of Osun State. International Journal of Contemporary Issues in Education (Special Edition) Vol. 1, pp. 92-96.
[18] Hammond, C., D, L., Smink, J., \& Drew, S. (2007). Dropout risk factors and exemplary programs: A technical report. Clemson, S.C.: National Dropout Prevention Center/Network \& Communities in Schools, Inc.

[19] Heilbrunn, J. Z. (2007). Pieces of the Truancy Jigsaw: A Literature Review. Denver, Colo.: National Center for School Engagement. Available at http://www.schoolengagement.org/TruancypreventionRegi stry/Admin/Resources/Resources/PiecesoftheTruancyJigsa wALiteratureReview.pdf.

[20] Henry, K. L. 2007. "Who's skipping school: Characteristics of truants in 8th and 10th Grade?" Journal of School Health 77(1):29-35.

[21] Henry, K. L., \& Huizinga D. H. (2007a). Schoolrelated risk and protective factors associated with truancy among urban youth placed at risk." Journal of Primary Prevention 28(6):505-19.

[22] Henry, K. L., \& Huizinga D. H. (2007b). Truancy's effect on the onset of drug use among urban adolescents placed at risk. Journal of Adolescent Health 40(4):358.e9-17.

[23] Keys.W,(1994) What do students think about school? Teaching and Learning in the Secondary School ,21-34

[24] Kirk, S., Malcilm, H., Wilson, V., \& Davidson, J. (2003), Absenteeism from school: A study of its causes and effects in seven LEAs. The SCRE Center, University of Glasgow, Queens Printers

[25] Ma'aruf, I. (2005). Truancy among secondary school students in Kano City: Causes and remedies. Unpublished P.G.D.E. Project, Federal College of Education, Kano.

[26] Nansel, T. R., M. Overpeck, et al. (2001). Bullying Behaviors Among US Youth Prevalence and Association With Psychosocial Adjustment, Am Med Assoc. 285: 2094-2100

[27] Nwadiani M. (1994). Managing pupils attendance data for computerization. A Paper Presented at the NIERA - Computerization of Educational Data Conference, University of Benin, 21-24 June.

[28] Obayan, P.T. (2003). Realizing Nigerian millennium education dream. The UBE in O. Bamisaiye, Nwazuoke and Okediran (eds). Education this Millennium, Ibadan.

[29] Obemeata, J.O. (1995). Education: An unproductive industry in Nigeria. Postgraduate School Interdisciplinary Research Discourse delivered at University of Ibadan, Ibadan.

[30]Office of Juvenile Justice and Delinquency Prevention (OJJDP), U.S. Department of Justice, Office of Justice Programs. 2003. OJJDP News @ a Glance II(1):1. Availableathttp://www.ncjrs.gov/html/ojjdp/news_at_glanc e/2003_2/jj_priorities.html.

[31] Oghuvu, E.P. (2006). Data inquiry and analysis for effective administration. A comparative study of private 
and public secondary schools. Journal of Social Science, Vol. 13(3): 205-213.

[32] Oghuvu, E.P. (2010), Absenteeism and lateness among secondary school students in Nigeria: Profiling causes and solution. Academic Leadership, On-line Journal, Vol. 8 (4).

[33] Okuyama, M., M. Okada, et al. (1999). Factors responsible for the prolongation of school refusal. Psychiatry and Clinical Neurosciences 53(4): 461-469

[34] Onouwodeke, M..A. (1995). The management of students' learning problems. Delta Journal of Educational Development, Abraka, 3(2): 81 - 90.

[35] Peck, C.K. (2002). Personality of high school truants. The Personnel and Guidance Journal, (2), 1, 16-22.

[36] Rumberger, R. W. (1987). High school dropouts: A review of issues and evidence. Review of Educational Research 57(2): 101-121.

[37] Reid, K. (1986). Disaffection from school. Publisher: Methuen\& Co in association with Methuen Inc, New York.

[38] Ryan, P. (2001). The school-to-work transition: A cross-national perspective. Journal of Economic Literature 39(1): 34-92.

[39] Seeley, K. (2008a). Truancy and connections to bad outcomes \& best practices." Presentation at the March 2008 Policy Forum: Truancy: The Absent Epidemic. Sponsored by the Office of State Superintendent of Education, District of Columbia. Available at http://www.seo.dc.gov/seo/frames.asp?doc=/seo/lib/seo/ser vices/pra/ken_seely_policy_forum_washingtonmarch08.pd f.

[40] Singhi, A.A. (1980), Personality of female truants. Indian Journal of Clinical Psychology, 52, 179-184.

[41] Siziya, S., Muula, A.S. \& Rudatsikira, E. (2007). Prevalence and correlates of truancy among adolescents in Swaziland; Findings from the global-school-based health survey. Journal of Child and Adolescent Psychiatry and Mental Health, Vol. 1 (1), 1-15.

[42] Smith, M. (1996). School attendance in Hertfordshire. Educational Research 38(2): 226-236.

[43] Ubogu, R.E. (2004). The causes of absenteeism and dropout among secondary school students in Delta Central Senatorial District of Delta State. Unpublished Ph.D Thesis. Delta State University, Abraka.

[44] Van Breda, M. J. (2006). Guidelines for empowering secondary school educators, in loco parentis, in addressing truancy among early adolescent learners, University of South Africa.

[45] Whitney, B. (1994). The Truth About Truancy, Routledge. 